\title{
VITAMIN D RECEPTOR (VDR) GENE POLYMORPHISM AND MATERNAL VITAMIN D DEFICIENCY IN INDIAN WOMEN WITH PRETERM BIRTH (PTB)
}

\author{
HITESH V PATEL ${ }^{1 *}$, NAYANA H PATEL ${ }^{2}$, NILOFAR R SODAGAR ${ }^{2}$
}

${ }^{1}$ Department of Biochemistry, Shri A. N. Patel PG Institute, Sardar Patel University, Anand - 388 001, Gujarat, India. ${ }^{2}$ Department of Gynecology and Obstetrics, Akanksha Hospital \& Research Institute, Anand - 387 310, Gujarat, India. Email: hvphitesh@rediffmail.com

Received: 17 April 2017, Revised and Accepted: 27 May 2017

\section{ABSTRACT}

Objective: Preterm birth (PTB) is the leading cause of high infant mortality and long-term disability in young children worldwide. Array of adverse maternal and fetal outcomes linked with vitamin D level and its associated vitamin D receptor (VDR) gene. We undertook this study to investigate the association between VDR gene polymorphism with vitamin D deficiency and PTB in West Indian pregnant women.

Methods: A total of 72 women with PTB and 138 healthy mothers with uncomplicated normal delivery were selected from different regions of Gujarat, India. FokI and TaqI single nucleotide polymorphism (SNP) of VDR gene determined by polymerase chain reaction and restriction fragment length polymorphism. Vitamin D level was determined using enzyme-linked immunosorbent assay.

Result: ff genotype (29.17\% vs. $10.87 \%$, p=0.002) and f allele ( $49.31 \%$ vs. $35.51 \%$, p=0.006) frequency distributions of VDR FokI showed significantly (odds ratio $=0.566,95 \%$ confidence interval=0.368-0.870, $\mathrm{p}=0.006$ ) higher in women with preterm delivery than in control full term group. Genotype frequency of VDR TaqI showed no significant difference between preterm group and control.

Conclusion: These results confirmed that women carrying ff genotype of FokI gene had significantly higher risk for vitamin D deficiency which enhances the risk of prematurity than women carrying FF genotype in West Indian women.

Keywords: Genetic polymorphism, Preterm birth, Vitamin D, Vitamin D receptor gene.

(C) 2017 The Authors. Published by Innovare Academic Sciences Pvt Ltd. This is an open access article under the CC BY license (http://creativecommons. org/licenses/by/4. 0/) DOI: http://dx.doi.org/10.22159/ajpcr.2017.v10i9.19236

\section{INTRODUCTION}

Prematurity represents major social and economic public health problem. It has an immense impact on individual family and healthcare system. Gestational age with $<37$ weeks is considered to be premature birth [1]. Preterm birth (PTB) is one of the largest causes of neonatal death globally. $35 \%$ of neonatal deaths are due to prematurity, an important contributor to child morbidities and longterm disability $[2,3]$. The prevalence of PTB varies among different ethnic groups. PTB rate is $16.3 \%$ in black women, $13 \%$ in American Indian, $11.3 \%$ in Hispanic, and $10 \%$ in Asian and Indian women $[4,5]$. The effect of genetic factors on PTB is difficult to understand due to the involvement of various environmental factors. It is needed to identify causes and effective way to prevent prematurity which could save countless infant lives. The development of nutritional status in children is strongly depending on maternal nutritional status. Maternal diet can alter gene expression during prenatal life and can increase susceptibility to individual to different disorder such as diabetes and hypertension [6]. Genetic polymorphism could increase the risk for the development of diseases in human population, which modify metabolic response to diet. Dietary vitamin D is efficiently absorbed in small intestine and transport to lymphatic system in chylomicrons. Vitamin D is a steroid hormone that maintains mineral homeostasis in the gastrointestinal tract and kidney. It modulates about $10 \%$ of the whole human genome and involved in developmental processes. Vitamin D homeostasis during pregnancy is an important for mother's health and progeny across a range of possible health outcomes $[7,8]$. Verity of adverse maternal outcomes [9] and offspring birth weight [10] demonstrated in pregnant women due to deficiency of vitamin D. The previous studies reported that a pregnant woman with lower level of vitamin D increases the risk of PTB in African-Americans and Caucasians population [11,12]. 1, 25-dihydroxyvitamin D (calcitriol) deficiency may be an independent risk factor for pregnancy and birth complications needed to study. Vitamin D produces its biological effects through binding with vitamin D receptor (VDR) present in bone, kidney, small intestine and neuronal cell which is a steroid hormone receptor and mediates gene expression $[13,14]$.

VDR possesses both ligand and DNA binding domains and it is located in the cytosol. VDR gene expression in placenta regulates various genes linked with implantation, maturity of fetus, and bone formation. Vitamin D status may influence intrauterine skeletal mineralization and growth during pregnancy [15]. VDR gene polymorphism may affect its expression, activity and subsequently downstream biological activity of vitamin D. Therefore, it could be a potent genetic marker for prematurity in pregnant women [16]. Several polymorphic sites have been described within VDR gene. Polymorphism near the 3' end of VDR gene identified by restriction enzyme BsmI, TaqI, ApaI, and FokI associated with osteoporosis [17], Type 1 diabetes mellitus [18], polycystic ovary syndrome [19], end-stage renal disease [20], several types of carcinoma such as breast, prostate, and colon carcinoma [21]. Therefore, genetic disparities of prematurity with regards to $V D R$ gene polymorphism need to be investigated. This study was conducted to explore the genetic inference of $V D R$ gene polymorphism on risk of PTB in West Indian women.

\section{METHODS}

\section{Study population}

The randomized cross-sectional study involved a total 210 women at the Department of Obstetrics and Gynaecology of Akanksha and Garima Hospital at Anand and Dr. Padma Gynaecology Hospital at Vadodara from October 2015 to May 2016. Written informed consent form and data collection sheets were obtained from all participated subjects. Subjects were classified into two groups; preterm group consisted of mothers who delivered their babies between 24 and 36 weeks and control group consisted mothers with uncomplicated normal delivery 
between 38 and 41 weeks. Anthropometric measurements of subject such as weight, height, body mass index (BMI), obstetrics history, and ethnicity were obtained from data collection sheet. Human Ethic Committee of Shri A. N. Patel PG Institute, Anand, has approved this study. Gynecologist calculated gestational age from last menstrual period and confirmed by ultrasonography. The inclusion criteria including healthy mother between the age of 20 and 35 years old, without any metabolic disordered with normal and healthy fetus were used to select subject. Pregnant women with a history of hyperuricemia, tuberculosis, diabetes, renal disease, and hypertension were excluded from the study. Abnormal fetus, preeclampsia, maternal age $>35$ years and stillbirth were also considered as exclusion criteria.

\section{Biochemical measurements}

Blood was drawn in anticoagulant-coated vacutainer blood collection tube and centrifuge at $5000 \mathrm{rpm}$ to separate serum. Serum was stored in deep freezer at $-20^{\circ} \mathrm{C}$ until analysis was performed. Total albumin was determined by bromocresol green kit method from serum. $250 \mathrm{H}$ vitamin D was measured using a commercially available enzyme-linked immunosorbent assay (DIA source Immunoassays, Belgium) kit on microtiter plates and expressed in $\mathrm{ng} / \mathrm{dl}$.

\section{Isolation of genomic DNA}

Genomic DNA was isolated from the collected fresh blood by G-Biosciences DNA extraction kit (OmniPrep ${ }^{\mathrm{TM}}$ Himedia Kit) and used for genotyping. Isolated genomic DNA was confirmed for quality by electrophoresis in $0.8 \%$ agarose gel.

\section{VDR genotyping}

Polymerase chain reaction (PCR) and restriction fragment length polymorphism (RFLP) were performed for genotyping of single nucleotide polymorphisms (SNPs): FokI (rs10735810) and TaqI (rs731236) of VDR gene. Amplification of selected gene was carried out by PCR using thermocycler machine (Thermo Scientific). Primers and restriction enzymes were purchased for Eurofine, Europe. FokI polymorphic site was amplified using following specified primer set described previously [22].

\section{FP: 5'-AGCTGGCCCTGGCACTGACTCTGCTCT-3',}

\section{RP: 5' ATGGAAACACCTTGCTTCTTCTCCCTC-3'.}

The following primer set was used to amplify TaqI polymorphic site according to [23].

\section{FW: 5'-CAGAGCATGGACAGGGAGCAA-3'}

\section{RP: 5'-CACTTCGAGCACAAGGGGCGTTAGC-3’.}

PCR condition and pattern of RFLP is mention in Table 1. PCR product was resolved on $2-3 \%$ agarose gel and visualized under UV light and further used for RFLP. PCR product ( $265 \mathrm{bp}$ ) contains FokI polymorphic site was digested for overnight at $37^{\circ} \mathrm{C}$ with FokI restriction enzyme. Amplified TaqI polymorphic segment (740 bp) was digested for $4 \mathrm{hrs}$ at $55^{\circ} \mathrm{C}$ with TaqI restriction enzyme. Restriction digested products were resolved by electrophoresis in $12 \%$ polyacrylamide gel stained with silver or by $2-3 \%$ agarose gel contained $0.5 \mu \mathrm{g} / \mathrm{ml}$ ethydium bromide using electrophoresis system (Bio-Rad) and visualized under UV transilluminator system.

\section{Statistical analysis}

Unpaired two-tailed Student's t-test was utilized to determine comparison between means. Pearson Chi-square $\left(\chi^{2}\right)$ test was used to compare categorical variables and genotypic frequencies from Hardy-Weinberg equilibrium for each SNP. Odds ratios (ORs) and 95\% confidence interval (95\% CI) were obtained using $\chi^{2}$ unbiased risk estimation. The statistical analyses were performed with the help of SPSS statistical software. A $p<0.05$ was considered statistically significant.

\section{RESULTS}

A total of 210 subjects including 72 preterm and 138 healthy controls belonging to the same ethnicity were analyzed for VDR gene polymorphism and its association with maternal vitamin D deficiency. Studied polymorphisms were found in Hardy-Weinberg equilibrium. The demographic and clinical characteristics of 210 participated women were summarized in Table 2 . The mean age $29.01 \pm 4.92$ years of the control group is nonsignificantly differed from preterm group with mean age $28.4 \pm 5.6$ years. The percentage of previous miscarriage cases was higher $(18 \%)$ in women with prematurity compared to control group $(7 \%)$. Women with PTB had significantly $(\mathrm{p}<0.05)$ lower level of vitamin $\mathrm{D}(18.7 \pm 5.2 \mathrm{ng} / \mathrm{ml})$ in serum compared to control subjects $(29.3 \pm 8.1 \mathrm{ng} / \mathrm{ml})$. The prevalence of vitamin D deficiency is significantly higher in women with PTB than in control women with full-term birth (Table 2).

The allele and genotype frequency distribution of VDR (FokI) gene among women with preterm delivery and control women with fullterm delivery is shown in Table 3. The genotype frequency of VDR FokI and TaqI was agreement with Hardy-Weinberg equilibrium in all groups in present study. FF, Ff, and ff genotypes were observed after RFLP of VDR (Fokl) PCR products (Fig. 1). In preterm group, FF, Ff, and ff genotypes accounts for $30.55 \%, 40.28 \%$, and $29.17 \%$ compared to $39.86 \%, 49.27 \%$, and $10.87 \%$ in control group, respectively. Preterm women showed significantly $(p<0.05)$ higher frequency of ff genotypes compared to control group. The frequency of $f$ allele was higher in preterm women than full-term women $(49.31 \%$ vs. $35.51 \%$; OR $=0.57$; 95\% CI=0.37-0.87; $\mathrm{p}=0.006$ ) compared to wild-type $\mathrm{F}$ allele. Preterm women carrying ff genotypes (FokI gene) had significantly higher risk for vitamin D deficiency than women with FF and Ff genotypes.

In women with $\mathrm{PTB}$, the $\mathrm{TT}$, $\mathrm{Tt}$ and tt genotypes of VDR TaqI polymorphism accounts for $35(48.61 \%), 31(43.06 \%)$ and $06(8.33 \%)$ compared to $72(52.17 \%), 54(39.13 \%)$ and $12(8.7 \%)$ in control subjects, respectively (Table 4 ). There was no significant difference in all genetic model (TT vs. Tt, $\mathrm{p}=0.59$ and TT vs. $\mathrm{tt}, \mathrm{p}=0.96$ ) between preterm women and control group for VDR TaqI polymorphism. Fig. 2 exhibits PCR-RFLP pattern obtained in VDR TaqI polymorphism. The frequency of T alleles $(70.14 \%$ vs. $71.71 \%)$ and t alleles $(29.86 \%$ vs. $28.26 \%)$ of VDR TaqI polymorphism was observed to be nonsignificantly differ $(\mathrm{p}=0.73)$ between PTB group and control group, respectively.

Table 1: PCR-RFLP protocol for FokI and TaqI polymorphism of VDR gene

\begin{tabular}{|c|c|c|c|c|}
\hline Polymorphism & Set of primers & $\begin{array}{l}\text { Annealing } \\
\text { temperature }\left({ }^{\circ} \mathrm{C}\right)\end{array}$ & $\begin{array}{l}\text { Size of PCR } \\
\text { product }\end{array}$ & RFLP pattern \\
\hline FokI (T/C) & $\begin{array}{l}\text { Forward primer: } \\
\text { 5'-AGCTGGCCCTGGCACTGACTCTGCTCT-3' } \\
\text { Reverse primer: } \\
\text { 5'-ATGGAAACACCTTGCTTCTTCTCCCTC-3' }\end{array}$ & $61^{\circ} \mathrm{C}$ & $265 \mathrm{bp}$ & $\begin{array}{l}\text { FF-265 } \\
\text { Ff-265, 196, } 69 \\
\text { ff-196, } 69\end{array}$ \\
\hline $\operatorname{TaqI}(\mathrm{C} / \mathrm{T})$ & $\begin{array}{l}\text { Forward primer: 5'-CAGAGCATGGACAGGGAGCAA-3' } \\
\text { Reverse primer: 5'-CACTTCGAGCACAAGGGGCGTTAGC-3' }\end{array}$ & $64^{\circ} \mathrm{C}$ & 740 bp & $\begin{array}{l}\text { TT- } 495,245 \\
\text { Tt- } 495,245,205,290 \\
\text { tt- } 205,245,290\end{array}$ \\
\hline
\end{tabular}

PCR: Polymerase chain reaction, RFLP: Restriction fragment length polymorphism, VDR: Vitamin D receptor 
The genotype frequency did not differ significantly by age and BMI between PTB and control women. We observed significantly $(\mathrm{p}<0.01)$ lower level of serum vitamin $\mathrm{D}$ in women with ff genotype $(15.24 \pm 2.31 \mathrm{ng} / \mathrm{ml})$ than in women with FF $(28.65 \pm 7.23 \mathrm{ng} / \mathrm{ml})$ and $\mathrm{Ff}$ $(24.36 \pm 4.51 \mathrm{ng} / \mathrm{ml})$ genotypes, respectively (Table 5). The relationship between FokI polymorphism in VDR gene and onset pattern of

Table 2: Demographic characteristics of subjects

\begin{tabular}{lll}
\hline Characteristics & Control & Preterm \\
\hline Sample (n) & 138 & 72 \\
Mean age \pm SD (year) & $29.01 \pm 4.92$ & $28.4 \pm 5.6$ \\
Married status (\%) & 100 & 100 \\
Previous miscarriage (\%) & 12 & $21^{*}$ \\
BMI $\left(\mathrm{kg} / \mathrm{m}^{2}\right)$ & $27.8 \pm 1.5$ & $23.4 \pm 2.7$ \\
SBP $(\mathrm{mmHg})$ & $135 \pm 12.11$ & $135.2 \pm 15.11$ \\
DBP $(\mathrm{mmHg})$ & $77.0 \pm 6.84$ & $76.8 \pm 8.68$ \\
$250 H$ Vitamin D $(\mathrm{ng} / \mathrm{ml})$ & $29.3 \pm 8.1$ & $18.7 \pm 5.2^{*}$ \\
\hline
\end{tabular}

${ }^{*} \mathrm{p}<0.05$ is considered as statistically significant. BMI: Body mass index,

SBP: Systolic blood pressure, DBP: Diastolic blood pressure

Table 3: Genotyping and allele frequency of FokI SNP in VDR gene between control and preterm cases

\begin{tabular}{lllll}
\hline $\begin{array}{l}\text { Polymorphic } \\
\text { genotype }\end{array}$ & $\mathbf{n}(\mathbf{6})$ & p value & OR (95\% CI) \\
\cline { 2 - 4 } & Control & Preterm & & \\
\hline FF & $55(39.86)$ & $22(30.55)$ & & \\
Ff & $68(49.27)$ & $29(40.28)$ & 0.849 & $0.94(0.46-1.90)$ \\
ff & $15(10.87)$ & $21(29.17)$ & $0.002^{* *}$ & $0.29(0.12-0.71)$ \\
Alleles & & & & \\
F & $178(64.49)$ & $73(50.69)$ & $0.006^{* *}$ & $0.57(0.37-0.87)$ \\
f & $98(35.51)$ & $71(49.31)$ & & \\
\hline${ }^{* *}<<0.01$ is considered as statistically significant. VDR: Vitamin D receptor,
\end{tabular}

SNP: Single nucleotide polymorphism, OR: Odds ratio, CI: Confidence interval

Table 4: Genotyping and allele frequency of TaqI SNP in VDR gene between control and preterm cases

\begin{tabular}{lllll}
\hline $\begin{array}{l}\text { Polymorphic } \\
\text { genotype }\end{array}$ & $\mathbf{n}(\%)$ & p value & OR (95\% CI) \\
\cline { 2 - 3 } & Control & Preterm & & \\
\hline $\mathrm{TT}$ & $72(52.17)$ & $35(48.61)$ & & \\
$\mathrm{Tt}$ & $54(39.13)$ & $31(43.06)$ & 0.59 & $0.85(0.45-1.61)$ \\
$\mathrm{tt}$ & $12(8.7)$ & $06(8.33)$ & 0.96 & $0.97(0.30-3.20)$ \\
Alleles & & & & \\
$\mathrm{T}$ & $198(71.74)$ & $101(70.14)$ & 0.73 & $0.93(0.58-1.48)$ \\
$\mathrm{t}$ & $78(28.26)$ & $43(29.86)$ & & \\
\hline
\end{tabular}

VDR: Vitamin D receptor, SNP: Single nucleotide polymorphism, OR: Odds ratio, CI: Confidence interval prematurity was observed significantly but not shown significance in TaqI polymorphism. In this study, FokI variant (ff genotypes) of VDR gene was identified genotype associated with maternal vitamin D deficiency in Indian women with PTB.

\section{DISCUSSION}

Maternal or fetal genetic predisposition has been suggested as one of the strongest risk factors for individual risk of prematurity. It also

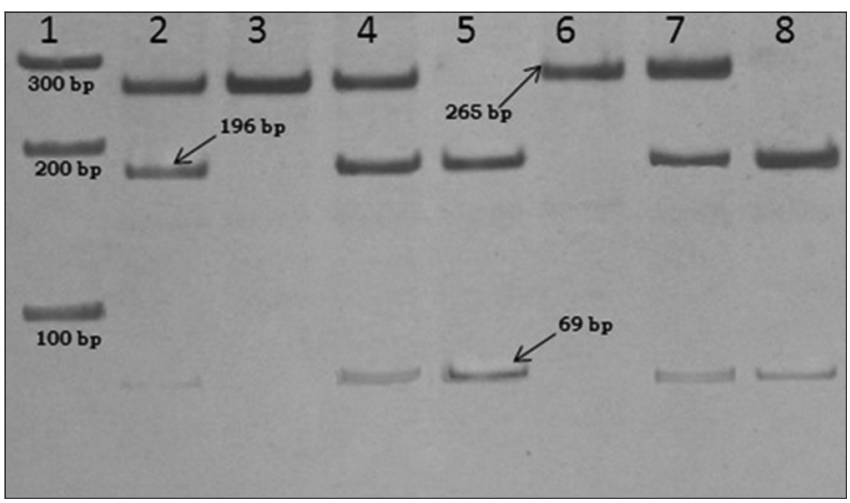

Fig. 1: Gel electrophoresis related to FokI polymorphism exhibits different genotype groups using polymerase chain reaction and restriction fragment length polymorphism. Lane 1 shows DNA marker, Lane 3, 6: FF genotype lacked a Fok-I site, Lane 5, 8: ff genotype, Lane: 2, 4, 7: heterozygote Ff genotype

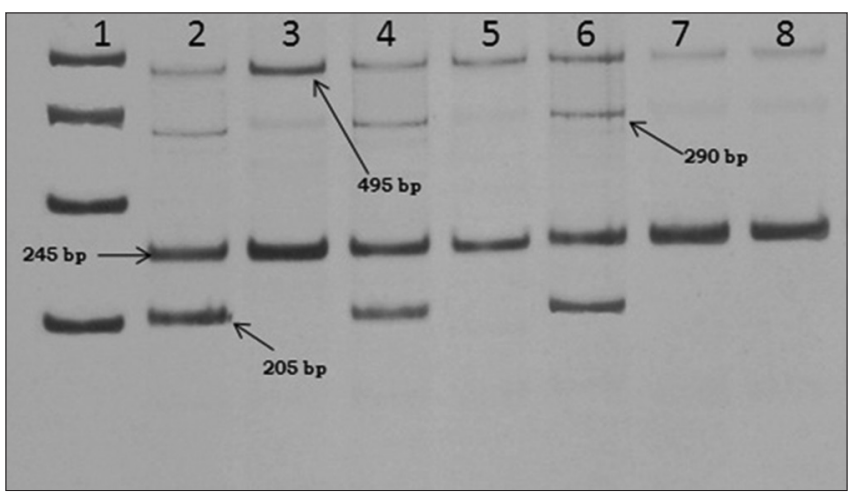

Fig. 2: Genotyping of VDR TaqI polymorphism observed using polymerase chain reaction and restriction fragment length polymorphism technique. Lane 1: DNA marker, Lane $3,5,7,8$ : Homozygous TT genotype, Lane 2, 4, 6: Heterozygous Tt genotype

Table 5: Heterogeneity in mean \pm SD values of different biochemical traits according to the genotypes of VDR polymorphism in participated women subjects

\begin{tabular}{|c|c|c|c|c|c|}
\hline \multicolumn{6}{|l|}{ FokI genotype } \\
\hline Biochemical traits & FF & Ff & ff & $\begin{array}{l}p \text { value } \\
\text { FF versus Ff }\end{array}$ & $\begin{array}{l}p \text { value } \\
\text { FF versus ff }\end{array}$ \\
\hline Age (year) & $27.4 \pm 4.87$ & $26.34 \pm 4.98$ & $26.39 \pm 5.39$ & 0.49 & 0.63 \\
\hline BMI $\left(\mathrm{kg} / \mathrm{m}^{2}\right)$ & $26.12 \pm 2.34$ & $25.64 \pm 2.87$ & $23.21 \pm 2.47$ & 0.55 & 0.42 \\
\hline Vitamin D level (ng/ml) & $28.65 \pm 7.23$ & $24.36 \pm 4.51$ & $15.24 \pm 2.31$ & 0.18 & $<0.01^{* *}$ \\
\hline \multicolumn{6}{|l|}{ TaqI genotype } \\
\hline Biochemical traits & TT & $\mathbf{T t}$ & tt & $\begin{array}{l}p \text { value } \\
\text { TT versus Tt }\end{array}$ & $\begin{array}{l}p \text { value } \\
\text { TT versus tt }\end{array}$ \\
\hline Age & $28.3 \pm 3.74$ & $29.12 \pm 4.76$ & $26.74 \pm 5.02$ & 0.41 & 0.50 \\
\hline BMI $\left(\mathrm{kg} / \mathrm{m}^{2}\right)$ & $25.45 \pm 1.85$ & $26.47 \pm 2.31$ & $24.74 \pm 1.89$ & 0.39 & 0.62 \\
\hline Vitamin D level (ng/ml) & $25.74 \pm 4.56$ & $22.34 \pm 9.34$ & $23.45 \pm 8.63$ & 0.27 & 0.42 \\
\hline
\end{tabular}

${ }^{* *} \mathrm{p}<0.01$ is considered as statistically significant. BMI: Body mass index, VDR: Vitamin D receptor, SD: Standard deviation 
caused by infection and inflammation. Preterm labor and PTBs are still one of the leading causes of perinatal morbidity and mortality in the developed world [24]. In the current study, we investigated the possible contribution of VDR gene polymorphism in susceptibility to prematurity among West Indian pregnant women. Our results revealed that serum levels of $25(\mathrm{OH}) \mathrm{D}$ were significantly $(\mathrm{p}<0.05)$ lower in women with PTB than in control subjects which confirm that vitamin D deficiency is a risk factor for prematurity.

The relationship of vitamin D insufficiency with PTB during pregnancy has been attracted by public health attention. PTB in women could increase by $59 \%$ with vitamin D level at or below $20 \mathrm{ng} / \mathrm{ml}$ [25]. The previous meta-analysis studies also confirmed the association between vitamin D insufficiencies and PTB $[12,26]$. This is the first study carried out to analyze the prevalence of vitamin D deficiency in West Indian women and its impact on prematurity. This study revealed that prevalence of vitamin D deficiency was considerably higher in women with PTB compared to control group. Adequate vitamin D status during pregnancy could reduce the risk of preterm delivery due to its decreasing placental colonization by bacterial vaginosis species [27]. PTB in women with vitamin D deficiency could be due to its contribution in activating innate immune response in placenta [28] and increased bacterial infection in maternal and fetal cell [27].

Transcriptional activity of the VDR gene regulates the transcription of about $3 \%$ of the human genome including genes that are crucial for preterm delivery. Vitamin D participates in the regulation of bone remodeling and mineral homeostasis. Due to involvement in fetomaternal interface (site of PTB) and also in ameliorates function, VDR system may serve as risk markers for PTB. Placental tissue obtained with PTB exhibited reduced mRNA expression of VDR gene compared to normal placental tissue [29]. Allele F in VDR produce shorter protein by three amino-acids which are more active form in transactivation of the VDR and producing 1, $25(\mathrm{OH})$ D effect compared to f allele of VDR gene [30]. Results of the present study indicated that subjects with ff genotype have significantly more risk to develop PTB compared with the reference genotype FF. Our results are consistent with the previous study which established an association between VDR FokI polymorphism and prematurity in a Saudi population [31]. Therefore, VDR FokI gene polymorphism showed an association with the occurrence of PTB in studied population. Spontaneous idiopathic PTB in an Israeli population was associated with FokI polymorphism in VDR receptor [15].

Contradictory results were found in study carried out by Cai et al. [32] which showed FF genotype of VDR FokI genotype was associated with increased risk of preterm delivery. A new Danish study indicates that genetic variations are associated with low levels of vitamin D in the blood leads to premature death [33]. In the present study, it is observed that pregnant women with lower level $(>20 \mathrm{ng} / \mathrm{mL})$ of vitamin $\mathrm{D}$ in serum have increasing risk of PTB.

TaqI located in 3' untranslated region should be related to VDR activity and expression [13]. Our results are also consistent with previous studies in which no relationship between $V D R$ (TaqI) polymorphisms and PTB was found. TaqI polymorphism is located in the non-coding region of the $V D R$ gene, and they do not have any effect on the final protein product. The TaqI genotype/allele distribution pattern in our study did not yield any significant results. A number of other potential candidate gene variants have been reported that predispose women for PTB. Subjects with deficient in vitamin D level are more susceptible to microbial infection and have a major risk factor for PBT [34]. Immunomodulating activity of vitamin $\mathrm{D}$ on cytokine production by endometrial cells of women plays an important role in etiology of PTB [35]. This study helps scientists to understand the complex genetic factor associated with an increased risk of PTB and valuable for effective ways to prevent or delay PTBs.

\section{CONCLUSION}

Our results indicated that FokI polymorphism of VDR gene may contribute to maternal vitamin D deficiency and increases PTB in Indian Women. Further, studies involving other genetic linkage assessment are required to evaluate the direct effect of VDR gene polymorphism in the development of PTB.

\section{ACKNOWLEDGMENT}

This study was supported by research grant from Gujarat Council on Science and Technology, Department of Science and Technology, Government of Gujarat (GUJOCST/MRP/2014-15/2566). We are grateful to staffs at Department of Obstetrics and Gynaecology of Akanksha Hospital, Garima Hospital and Dr. Padma Gynaecology Hospital for their support in collection of blood samples, subject selection and demographic data collection of the present study.

\section{REFERENCES}

1. López NJ, Smith PC, Gutierrez J. Periodontal therapy may reduce the risk of preterm low birth weight in women with periodontal disease: A randomized controlled trial. J Periodontol 2002;73(8):911-24.

2. Blencowe H, Cousens S, Oestergaard MZ, Chou D, Moller AB, Narwal R, et al. National, regional, and worldwide estimates of preterm birth rates in the year 2010 with time trends since 1990 for selected countries: A systematic analysis and implications. Lancet 2012;379(9839):2162-72.

3. Liu NQ, Hewison M. Vitamin D, the placenta and pregnancy. Arch Biochem Biophys 2012;523:37-47.

4. Howson CP, Kinney M, Lawn JE. March of dimes, PMNCH, save the children, WHO. Born Too Soon: The Global Action Report on Preterm Birth. Geneva: World Health Organization; 2012.

5. Bhavnani S, Dang B, Caro M, Saade G, Visweswaran S. Genetic differences reveal heterogeneity in spontaneous preterm birth pathophysiology: A visual analytical approach. Am J Obstet Gynecol 2014;210:S343-4.

6. Sherzay N, Chitakar E. Epigenetics: Effect of environmental factors on human genome. Int J Pharm Pharm Sci 2016;8(3):1-6.

7. Kovacs CS. Vitamin D in pregnancy and lactation: Maternal, fetal, and neonatal outcomes from human and animal studies. Am J Clin Nutr 2008;88(2):520S-8.

8. Lewis S, Lucas RM, Halliday J, Ponsonby AL. Vitamin D deficiency and pregnancy: From preconception to birth. Mol Nutr Food Res 2010;54(8):1092-102.

9. Dror DK, Allen LH. Vitamin D inadequacy in pregnancy: Biology, outcomes, and interventions. Nutr Rev 2010;68(8):465-77.

10. Reichetzeder C, Chen H, Föller M, Slowinski T, Li J, Chen YP, et al. Maternal vitamin D deficiency and fetal programming - Lessons learned from humans and mice. Kidney Blood Press Res 2014;39(4):315-29.

11. Mohamed SA, Thota C, Browne PC, Diamond MP, Al-Hendy A. Why is preterm birth stubbornly higher in African-Americans? Obstet Gynecol Int J 2014;1(3). pii: 00019.

12. Qin LL, Lu FG, Yang SH, Xu HL, Luo BA. Does maternal vitamin D deficiency increase the risk of preterm birth: A meta-analysis of observational studies. Nutrients 2016;8(5). pii: E301.

13. Valdivielso JM, Fernandez E. Vitamin D receptor polymorphisms and diseases. Clin Chim Acta 2006;371(1-2):1-12.

14. Zam W. Vitamin D deficiency and depressive disorders: Review study of probable relationship. Int J Pharm Pharm Sci 2016;8(1):16-22.

15. Manzon L, Altarescu G, Tevet A, Schimmel MS, Elstein D, Samueloff A, et al. Vitamin D receptor polymorphism FokI is associated with spontaneous idiopathic preterm birth in an Israeli population. Eur $\mathrm{J}$ Obstet Gynecol Reprod Biol 2014;177:84-8.

16. Gao L, Tao Y, Zhang L, Jin Q. Vitamin D receptor genetic polymorphisms and tuberculosis: Updated systematic review and meta-analysis. Int J Tuberc Lung Dis 2010;14(1):15-23.

17. Moran JM, Pedrera-Canal M, Rodriguez-Velasco FJ, Vera V, Lavado-Garcia JM, Fernandez P, et al. Lack of association of vitamin $\mathrm{D}$ receptor BsmI gene polymorphism with bone mineral density in Spanish postmenopausal women. PeerJ 2015;3:e953.

18. Al-Moubarak S, Haddad S. Gender-specific association of vitamin D receptor polymorphism Bsm-I with Type 1 diabetes mellitus. Int J Pharm Sci Rev Res 2013;21(2):254-7. 
19. Sur D, Chakravorty R. Genetic polymorphism in the vitamin D receptor gene and 25-hydroxyvitamin D serum levels in East Indian women with polycystic ovary syndrome. J Mol Biomarkers Diagn 2015;6:294.

20. Yokoyama K, Shigematsu T, Tsukada T, Ogura Y, Takemoto F, Hara S, et al. Apa I polymorphism in the vitamin D receptor gene may affect the parathyroid response in Japanese with end-stage renal disease. Kidney Int 1998;53:454-8.

21. Aldabagh MA, Mohaymen NA, Al-Mayah QS, Jasem IA. Impact of Fok-I polymorphism of vitamin D receptor (VDR) gene and vitamin D status in bladder cancer incidence. Int J Curr Microbiol Appl Sci 2015;4(11):783-91.

22. Harris SS, Eccleshall TR, Gross C, Dawson-Hughes B, Feldman D. The vitamin $\mathrm{D}$ receptor starts codon polymorphism (FokI) and bone mineral density in premenopausal American black and white women. J Bone Miner Res 1997;12:1043-8.

23. Riggs BL, Nguyen TV, Melton LJ $3^{\text {rd }}$, Morrison NA, O'Fallon WM, Kelly PJ, et al. The contribution of vitamin D receptor gene alleles to the determination of bone mineral density in normal and osteoporotic women. J Bone Miner Res 1995;10(6):991-6.

24. Robert LG, Culhane JF, Iams JD, Romero R. Epidemiology and causes of preterm birth. Lancet 2008;371(9606):75-85.

25. Wagner CL, Baggerly C, McDonnell S, Baggerly KA, French CB, Baggerly L, et al. Post-hoc analysis of vitamin D status and reduced risk of preterm birth in two vitamin D pregnancy cohorts compared with South Carolina march of dimes 2009-2011 rates. J Steroid Biochem Mol Biol 2016;155:245-51.

26. Shibata M, Suzuki A, Sekiya T, Sekiguchi S, Asano S, Udagawa Y, et al. High prevalence of hypovitaminosis D in pregnant Japanese women with threatened premature delivery. J Bone Miner Metab 2011;29(5):615-20.

27. Grant WB. Adequate vitamin D during pregnancy reduces the risk of premature birth by reducing placental colonization by bacterial vaginosis species. MBio 2011;2(2):e00022-11.

28. Liu N, Kaplan AT, Low J, Nguyen L, Liu GY, Equils O, et al. Vitamin D induces innate antibacterial responses in human trophoblasts via an intracrine pathway. Biol Reprod 2009;80(3):398-406.

29. Fischer D, Schroer A, Lüdders D, Cordes T, Bücker B, Reichrath J, et al. Metabolism of vitamin D3 in the placental tissue of normal and preeclampsia complicated pregnancies and premature births. Clin Exp Obstet Gynecol 2007;34(2):80-4

30. O’Neill V, Asani FF, Jeffery TJ, Saccone DS, Bornman L. Vitamin D receptor gene expression and function in a South African population: Ethnicity, vitamin D and FokI. PLoS One 2013;8(6):e67663.

31. El-Beshbishy HA. Association of vitamin D receptor gene polymorphisms with gestational diabetes in pregnant women. Wulfenia J 2014;21(9):302-8.

32. Cai W, Shen XY, Zhu BP, Pan SL. Relationship between vitamin D receptor gene polymorphism and preterm birth. Nan Fang Yi Ke Da Xue Xue Bao 2016;36(9):1276-80.

33. Brix L. Genetically Low Vitamin D Concentrations Cause Premature Death: A New Danish Study Indicates that Gene Variations, which are Associated with Low Levels of Vitamin D in the Blood, Can Lead to Premature Death. It is not yet known whether Dietary Supplements Can Counteract This Effect. November, 24; 2014. Available from: http:// www.sciencenordic.com.

34. Al-Shaikh GK, Ibrahim GH, Fayed AA, Al-Mandeel H. Impact of vitamin D deficiency on maternal and birth outcomes in the Saudi population: A cross-sectional study. BMC Pregnancy Childbirth 2016;16:119

35. Ibrahim ZM, Elhan HM, Radwa MA, Magda ME. Role of 1, 25-dihyroxyvitamin D (vitamin D3) as immunododulator in recurrent missed miscarriage. Middle East Fertil Soc J 2013;18(3):171-6. 